American Journal of Applied Sciences 5 (6): 698-704, 2008

ISSN 1546-9239

(C) 2008 Science Publications

\title{
Policies to Enhance Water Sector in Jordan
}

\author{
Zeyad S. Tarawneh, Nidal A. Hadadin and Ahmad N. Bdour \\ Civil Engineering Department, \\ The Hashemite University, \\ 13115 Zarqa, Jordan
}

\begin{abstract}
We suggested general polices that can be implemented to improve the sustainability and serviceability of the water sector in Jordan. It is suggested that water legislations in Jordan need to be updated to expand the involvement of the private sector to retain sustainable maintenance programmes that effectively mend water distribution systems. Moreover, water resources should be reallocated among competing sectors considering priority to users with purposes that are deemed to have the higher returns in economic and social terms. It is suggested that activating public awareness programmes will raise community understanding and support for water allocation plans among competing water use sectors and improve public participation in developing and accepting new policies related to water management.
\end{abstract}

Keywords: Water shortage, resources reallocation, private sector participation.

\section{INTRODUCTION}

Jordan is located in an arid to semi arid region where around $90 \%$ of the country's land receives an average precipitation of less than $100 \mathrm{~mm} /$ year while only $3 \%$ of the land receives an average annual precipitation of $300 \mathrm{~mm}$ or more. In general, Jordan is characterized by severe weather conditions, therefore great temporal and spatial variations in rainfall, runoff and evaporation amounts are expected. The rate of population growth in Jordan is about 3\% for the years 1998-2005, which is considered the ninth highest in the world as indicated by the population growth figures prepared by the Department of Statistics.

The total water utilized in Jordan is generally provided through various sources including renewable groundwater, surface water in the form of baseflows and reservoirs, treated wastewater not flowing into reservoirs and additional water resources. Surface water from the Yarmouk River, peace treaty water and non conventional water resources including desalinization and groundwater from non renewable aquifers are the major components forming the additional water resources $^{[1]}$. Figure 1 shows the distribution of water resources in Jordan in million cubic meters $\left(\mathrm{Mm}^{3}\right)$ and the percentage of each resource for the year 2005 as estimated by the Ministry of Water and Irrigation.
While water resources in Jordan are limited, the depletion of non-renewable resources due to over pumping from oppressed aquifers is considered a serious threat to the water sector in Jordan ${ }^{[2]}$. Moreover, the available renewable water resources are dropping drastically to an annual figure of $160 \mathrm{~m}^{3} / \mathrm{capita}$ in recent years compared to $3600 \mathrm{~m}^{3} / \mathrm{capita}$ for the year 1946. The dramatic decrease in both renewable and non-renewable resources is due to the steep population growth, rapid agricultural and industrial developments and the sudden influx of refugees due to political instability in the region ${ }^{[3]}$. In the year 2001, the country's total water demand was in the range of 1350 $\mathrm{Mm}^{3}$, of which, only $774 \mathrm{Mm}^{3}$ was supplied due to water shortages resulting from drought conditions.

Several previous studies relating to the water sector in Jordan have generally concluded that there is a need to focus attention on the future impact of water shortages through resources planning and development ${ }^{[2-6]}$. In summary, Jordan must give priority to the efficient management of the limited water resources at the regional level that includes institutional restructuring, new water pricing strategies, importation of water and water desalination to account for the increasing population growth and industrial activities. The adapted management plan should take into account the effect of political instability on regional cooperation among water-sharing countries.

Corresponding Author: Zeyad S. Tarawneh, Civil Engineering Department, The Hashemite University, 13115 Zarqa, Jordan, Tel: +962-53903333, Fax: +962-53826354, E-mail: zeyadt@ hu.edu.jo 


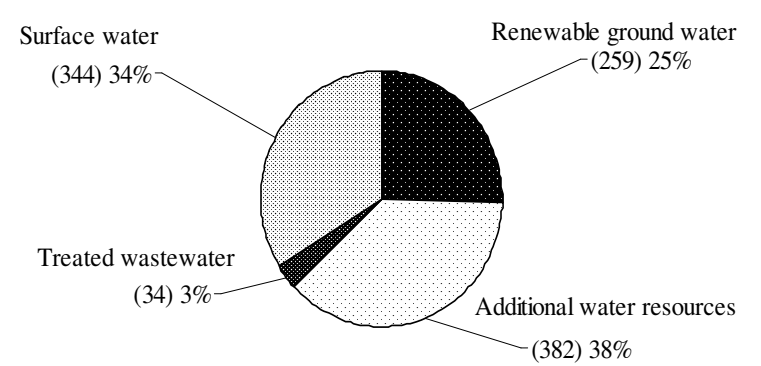

Fig.1: The distribution of water resources in Jordan in million cubic meters $\left(\mathrm{Mm}^{3}\right)$ and the percentage of each resource for the year 2005 .

In Jordan, water is consumed in satisfying the demands of the municipal, tourist, industrial and irrigational sectors. The annual municipal water consumption, in the context of this paper, refers to the water consumed in a given year by the domestic and commercial sectors in addition to light industries, while the tourist water consumption is the amount of water used by hotels and furnished apartments. The industrial water consumption refers to the amount of water consumed by industries that exploit water produced locally, mainly from deep wells, with the exception of the two major industries in Aqaba: the Thermal Power Station and Jordan Fertilizer Industry Company that are currently receiving their water from the public network.

The major irrigation activities in Jordan occur mainly in the Jordan Rift Valley. In addition to treated wastewater, surface water from the Yarmouk River and the side wadis is supplied by the Jordan Valley Authority. Other irrigation activities occur in the North eastern Desert and the Southern Desert where water is pumped from licensed or unlicensed private wells (renewable and non renewable groundwater) and, to a lesser extent, from surface water. Irrigation water consumption is defined as the amount of water actually consumed by crops being equivalent to determining the actual evapotranspiration. The majority of water used in Jordan is for agricultural activities and accounts for around $77.5 \%$ of all water consumed, with the rest being for municipal and industrial use. The annual growth in demand for water in Jordan is estimated at 25 $\mathrm{Mm}^{3} /$ year and is related to urbanization and industrial expansion as well as to increased domestic use, mainly as a result of population growth ${ }^{[3]}$.

Previous studies have suggested methods of increasing the water supply in Jordan through desalination of seawater and brackish water ${ }^{[2,8]}$, importation of water from neighbouring countries ${ }^{[5]}$, and intensive capturing of rainwater ${ }^{[9]}$, as well as other alternatives. However, all these are subject to cost benefit analysis and geopolitical constraints ${ }^{[3]}$. The aim of this paper is to suggest additional polices and procedures that can be implemented either fully or partially to enhance the performance and sustainability of the water sector in Jordan.

\section{MATERIALS}

Historic water consumption data related to competing water users in Jordan and projection of future demands presented in this study were obtained from records provided by the Ministry of Water and Irrigation. Future projections are based on the results obtained from the demand pre-processing modules currently deployed at the Ministry of Water and Irrigation, National Water Master Planning Directorate. Data for historic water losses from the municipal water distribution net were gathered from annual records provided by the Water Authority of Jordan.

\section{RESULTS AND DISCUSION}

Historic Water Consumption and Future Demands: Records of the municipal water consumption show that actual water consumption exceeds the billed amounts. Losses including water not accounted for due to illegal abstraction, non-operational water meters and unmetered connections are the major causes for the discrepancy between the actual water consumption and the billed amounts. The country's average percentage of water losses from the main water distribution net as estimated by the Water Authority of Jordan for the years $1999-2005$ is about $51 \%$ which is relatively high compared with values in developed countries. Figure 2 show the percentage of water losses from the public distribution net for the years 1999-2005.

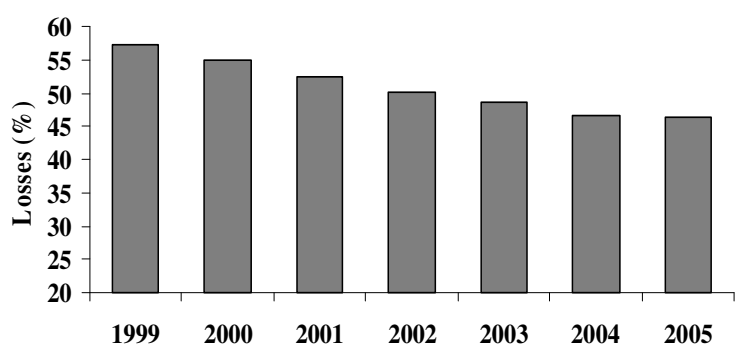

Fig.2: The percentage of water losses from the public distribution net for the years 1999-2005. 
Am. J. Applied Sci., 5 (6): 698-704, 2008

Table 1: Historic water demand per sector

\begin{tabular}{lcccccc}
\hline Sector & \multicolumn{7}{c}{ Historical water demand } \\
& 1996 & 1997 & 1998 & 1999 & 2000 & 2001 \\
\hline Municipal (1/c/d) & 103.8 & 97.2 & 94.7 & 89.8 & 86.7 & 85.9 \\
Tourist $\left(\mathrm{Mm}^{3}\right)$ & 1.97 & 1.99 & 1.59 & 2.17 & 2.06 & 1.83 \\
Industry $\left(\mathrm{Mm}^{3}\right)$ & 34.2 & 36.2 & 37.5 & 37.5 & 36.1 & 31.6 \\
Irrigation $\left(\mathrm{Mm}^{3}\right)$ & 875 & 869 & 834 & 803 & 811 & 765 \\
\hline
\end{tabular}

Table 2: Average historic consumption and future demands per sector

\begin{tabular}{lcccc}
\hline \multirow{2}{*}{ Sector } & \multicolumn{3}{c}{ Water demand $\left[\mathrm{Mm}^{3}\right]$} \\
& Average historic ${ }^{*}$ & 2010 & 2015 & 2020 \\
\hline Municipal and tourist & 165 & 415 & 460 & 513 \\
Industry & 36 & 77 & 100 & 120 \\
Irrigation & 826 & 1072 & 1040 & 983 \\
Total demand & 1027 & 1564 & 1600 & 1616 \\
Available resources $\left(\mathrm{Mm}^{3}\right)$ & 950 & 1244 & 1220 & 1250 \\
Population (million) & 4.75 & 7.0 & 8.1 & 9.2 \\
\hline
\end{tabular}

* Average is based on data for years 1996-2001.

Although the Water Authority of Jordan has taken several preventive procedures to reduce the water losses from the public distribution net as shown in Figure 2, the percentage of losses is still considered high and therefore further improvements are still needed. Values of municipal water consumption for the years 19962001 as estimated by the Water Authority of Jordan show an average consumption of $163 \mathrm{Mm}^{3} /$ year, which is equivalent to $94 \mathrm{l} / \mathrm{c} / \mathrm{d}$ (litre/capita/day). That value is extremely low compared with neighbouring countries that have an average water consumption in the range of $150-300 \mathrm{l} / \mathrm{c} / \mathrm{d}^{[2]}$. A nationwide decrease in the municipal water consumption from $104 \mathrm{l} / \mathrm{c} / \mathrm{d}$ in 1996 to $86 \mathrm{l} / \mathrm{c} / \mathrm{d}$ in the year 2001 has been observed (Table 1).

The decreasing per capita water share indicates the increasing pressure of the growing population on the limited water resources. The statistics provided by the Water Authority of Jordan show an average tourist consumption for the period 1996-2001 of around 2 $\mathrm{Mm}^{3} /$ year (Table 1). Generally, the governorates of Amman and Aqaba, where major touristic activities exist, have the biggest share of the tourist consumption due to the progressive tourist expansion in both governorates. Despite the increasing tourist activities during the past years, from 22735 bed units in 1996, to 37385 units in the year 2001, records show almost steady values for the historic amounts of water consumption (Table 1). This suggests that hotels are increasingly buying water from private licensed wells in order to maintain steady water supplies for their clients throughout the year. Records of some big hotels in Amman city show that water provided from private wells is about $40-50 \%$ of the annual consumption.

Mining and manufacturing are the major industries in Jordan. Typically, the industries of phosphate and potash mining, production of cement, petroleum refining and fertilizer production are the major industries in Jordan contributing to the biggest share of industrial water consumption. Although industrial activities have increased during the past two decades, recent records of water consumption show stability in consumption (Table 1). That stability is attributed to the development of in-site treatment and reuse technologies ${ }^{[10]}$. The average total amount of water used for industries during the years 1996-2001 is estimated at $36 \mathrm{Mm}^{3} /$ year (Table 1).

Studies conducted by the Ministry of Water and Irrigation indicate an increasing future demand on 
water for municipal, tourist and industrial uses (Table 2 ). The irrigation share as a percentage of the total water used in Jordan indicates a considerable decrease during the last two decades, i.e. from $78 \%$ in 1985 to $64 \%$ in the $2002^{[1]}$. In addition to water shortages resulting from persistent droughts, restrictions on well drilling, increasing control measures on private wells and the reduction in irrigated areas due to soil erosion and urbanization are the major factors contributing to that decrease ${ }^{[3]}$. The total irrigation demand, assuming unstressed conditions, i.e. year of median water budget, is forecast to decrease from $1072 \mathrm{Mm}^{3}$ in 2010 to 983 $\mathrm{Mm}^{3}$ in the year 2020 (Table 2). Factors that may lead to such a decrease are mainly the reduction in irrigated land due to erosion, urbanization and desertification processes through leeching soil of its nutrients ${ }^{[3]}$. Table 2 shows the average historic consumption and future demands per sector against the available water resources.

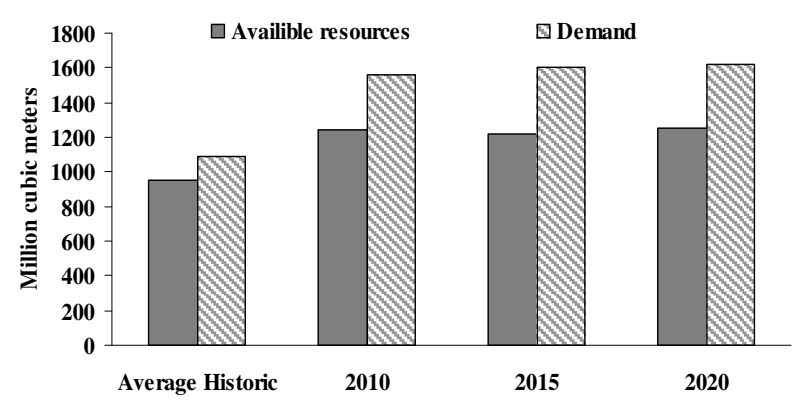

Fig.3: The average historic and future water demands versus available water resources.

Figure 3 mainly shows the increasing stress on water resources to fulfil the increasing demand due to population growth, expandable industrial and tourist activities.

Policies to Enhance the Water sector: This paper suggests general policies and procedures that can enhance the water sector in Jordan through water savings, effective management and increasing the water supply. The implementation of the proposed procedures is either fully or partially based on certain priorities that will lead to sustainable water services to meet the satisfaction of end users. The government of Jordan has already started to a certain extent the process of implementing procedures to enhance the water sector, however, it is necessary for further action to be considered. The procedures suggested by this paper to enhance the water sector in Jordan are:
- Rehabilitation of the water distribution net: Except for the newly developed regions in the city of Amman, parts of the main water distribution net in different locations in Jordan are considered relatively old, i.e. in the range of 35-45 years. The percentage of water losses from the public distribution net reported by the Water Authority of Jordan for the years 1999-2005 indicates an average rate of about $51 \%$ (Figure 2), which is relatively high compared to values in developed countries. The Water Authority of Jordan has taken steps to reduce losses by conducting intensive maintenance programmes. For the year 2005 the maintenance department has successfully tackled 1404 application in order to maintain the distribution net in different locations all over the country. However, considerable parts of the main distribution net, especially in suburban and rural regions, still lie above ground without appropriate cover. These parts of the distribution net are very exposed to damage, due to frost action in harsh winters and illegal connections by small farmers, especially during the hot summer seasons. Properly covering the above ground exposed parts of the net would reduce total water losses dramatically. Moreover, additional control measures can be initiated by installing water meters wherever needed to monitor water consumption in relation to billed amounts. In general, further studies need to be conducted to consider the under design problem of pipes which will help in reducing interruptions and thus increase the efficiency of the water supply for domestic and tourist purposes. In relation to irrigation, monitoring of irrigation networks should be employed to reduce losses through leakage and breaks. Moreover, preventive maintenance of pumps, motors and valves should be programmed and conducted periodically.

- Increasing water tariffs: Water services for domestic and tourist uses in the cities of Amman and Aqaba are mainly provided by the private sector. Compared with other cities in Jordan, the billing process in the cities of Amman and Aqaba is more efficient due to the application of water tariffs. In cities and towns where the government offers a water service, it is highly desirable that part of the capital cost of the services is recovered with a gradual increase in bills and finally targeting the full costs of the recovery of operation and maintenance processes. Proper maintenance programmes will reduce losses and consequently maintain the sustainability of the service. Different charges for different areas could be applied that should assess each geographical area 
taking into consideration economic and social situations of the end users. With regard to water provided for irrigation purposes, differential prices could be applied taking into account its quality, subject to economic constraints.

- Updating water arrangements and legislations: The present water laws are focused on defining institutional responsibilities rather than defining an overall comprehensive vision for the national water resources management. Currently, overlapping responsibilities appear in relation to different water sector institutions. Therefore it is recommended that a comprehensive water law is delivered that defines clearly the different responsibilities. Also, it is recommended periodically to review institutional arrangements and legislation in relation to appraising the adequacy of the water supply status through changing conditions and times. Updating legislation to expand the participation of the private sector will encourage private investments and hence in maintaining sustainable services to end users. In particular, management contracts, concessions and other forms of private sector participation in water utilities should be considered and adopted as appropriate. The participation of the private sector's role in irrigated agriculture should also be encouraged and expanded. Emphasis should be placed on the social benefits in conjunction with private investments.

- Reallocating water among sectors: The reallocation of water between competing sectors helps to reduce the consequences of water shortages for important sectors especially during dry seasons. In general, priority criterion for water allocation has to be based on economic, social and environmental considerations. It is recommended that the first priority of allocation of available resources is to users with purposes that are deemed to have high returns in economic and social terms, for example municipal, tourist and industrial sectors, while for agricultural use priority has to be given to sustaining existing irrigated projects where there are high capital investments. In particular, trees irrigated from groundwater should continue to receive an amount sufficient for their sustainability with the use of advanced irrigation methods, for example drip irrigation. Also priority should be given to agricultural projects irrigated by reservoirs of water whose quality does not qualify for use in municipal and industrial purposes.

- Public Awareness: Public awareness is primarily the process of informing and educating water users about the current and future situation of the water sector. Effective public awareness programmes greatly help service providers to manage water demand through educating end users to consume water rationally and to encourage them to conserve water. Moreover, public awareness programmes directly educate end users to confront the problem of resources' depletion and to understand its implications through seeing themselves as caretakers of resource sustainability. In general, public awareness programmes could be a conceivable replacement for other demand management methods, including raising water prices and introducing water-saving devices which may be less acceptable to the general public. In Jordan it is essential to conduct public awareness programmes at the national level since there is a general lack of understanding and concern about the value and scarcity of water resources. Awareness programmes need to be implemented through the media and schools to raise community understanding and support for water allocation among competing water use sectors and to improve public participation in developing and accepting new policies related to water management. These programmes should also target the modification of public behaviour to assist in reducing illegal water connections and the general misuse and damage of water measurement devices. Workshops and seminars to inform the private sector, mainly well owners and farmers need to be organized to promote groundwater conservation and raise the efficiency of groundwater use and reuse.

- Involvement of the private sector: The government of Jordan considers the participation of the private sector in managing the water industry as a major step to be achieved. Since 1999 the water supply in Amman city has been managed by the private sector, and major future water and wastewater projects are foreseen as involving further private sector participation. The government, although it has begun, needs to increase private sector participation through transferring infrastructure and services from the public to the private sector in order to improve the performance and ensure the delivery of services to the population. Legislation related to private sector investments in the water sector need to be updated and continually assessed in relation to the benefits and satisfaction of end users. The role of water tariffs should be considered as a tool to attract private investment in water projects targeting the recovery of the capital costs and costs of operation and maintenance. The role of the private sector in agricultural projects should also be encouraged and 
expanded with emphasis be placed on the social benefits in conjunction with private investments.

- Development of New Water Resources: During the last decade several large reservoirs have been established to collect the flood water of large valleys that provide considerable amounts of water for irrigation purposes. In the year 2005 the total capacity of reservoirs was estimated at $191 \mathrm{Mm}^{3}$; however, despite heavy investment in the construction of storage reservoirs there are still opportunities for further development in the surface water sector. In addition, large reservoirs and small desert dams can retain considerable quantities of flood water resulting from instantaneous heavy rainfalls over the desert eastern plains and hence help to increase the groundwater recharge and provide water for pastoral use. Moreover, rainfall-runoff drainage from the roofs of buildings can be collected and stored in small tanks that may serve as an additional water source for residential houses in urban areas. Non conventional water resources including treated wastewater reuse, desalination of brackish water, which can be operated privately by farmers for irrigation purposes, importation of water, and weather modification through cloud seeding are additional water sources that can be developed to increase the water budget.

\section{CONCLUSIONS AND RECOMMENDATIONS}

Jordan's future demand for water is expected to exceed the available water resources because of rapid population growth and the increasing agricultural, industrial and tourist activities. The development of new water resources to increase the water budget is regarded as a challenge to the government of Jordan. This paper suggests general polices that can be implemented to improve the sustainability and serviceability of the water sector in Jordan. Losses from the public water distribution net can be reduced to acceptable levels through conducting intensive maintenance programmes that include proper coverage for parts of the net that are exposed to the air, targeting the minimization of water leakage. Operational and maintenance services in cities and towns, where the private sector is not involved, can be improved by gradually recovering the costs of the services through applying a gradual increase in the bills and finally targeting the full recovery of the capital costs. Differential charges for different areas can be applied that consider the economic and social situation of the end users.
A comprehensive water law that defines clearly the responsibilities of the different water sector institutions is recommended to be issued. Also, it is recommended to update legislation that expands the participation of the private sector in both municipal and agricultural sectors including management contracts, concessions and other forms of private sector participation in water utilities. It is recommended that water service providers maintain priority strategies to allocate new water resources between competing sectors for users with purposes that are deemed to have the higher returns in economic and social terms such as municipal, tourist and industrial sectors.

In Jordan it is essential to conduct public awareness programmes at a national level to overcome the lack of understanding and concern about the value and scarcity of water resources. Awareness programmes can be implemented through the media and schools to raise community understanding and support for water allocation among competing water use sectors and to improve public participation in developing and accepting new policies related to water management. These programmes should also target the modification of public behaviour to assist in reducing illegal water connections and the general misuse and damage of water measurement devices.

Increasing the private sector participation through transferring infrastructure and services from the public to the private sector is necessary to improve performance and ensure the delivery of services to the population. Legislation related to private sector investments in the water sector need to be updated and continually assessed in relation to the benefits and satisfaction of end users. The role of water tariffs should be considered as a tool to attract private investment in water projects targeting the recovery of capital costs and the costs of operation and maintenance. Further development in the surface water sector is still needed including treated wastewater, desalination of brackish water and water harvesting projects that help to increase groundwater recharge and to provide water for pastoral use. Rainfall-runoff drainage from the roofs of buildings could be collected and stored in small tanks which may serve as an additional water source for residential houses in urban areas.

\section{ACKNOWLEDGEMENTS}

Authors like to acknowledge the ministry of water and irrigation, Jordan for providing data related to water sector in Jordan. 


\section{REFERENCES}

1. Ministry of Water and Irrigation, National Water Master Plan, Amman, Jordan, 2004.

2. J. Jaber and M. Mohsen, 2001. Evaluation of nonconventional water resources supply in Jordan. Desalination 136: 83-92.

3. N. Hadadin and Z. Tarawneh, 2007. Environmental issues in Jordan, solutions and recommendations. American Journal of Environmental Sciences 3 (1): 30-36.

4. O. Al-Jayyousi and M. Shatanawi, 1995. An analysis of future water policies in Jordan using decision support systems. International Journal of Water Resources Development 11 (3): 315-330.

5. M. Murakami, 1995. Managing water for peace in the middle east: alternative strategies. United Nation University Press, Tokyo, Japan, pp: 167201.
6. A. Abu-Awwad and M. Shatanawi, 1997. Water harvesting and infiltration in arid areas affected by surface crust: examples from Jordan. Journal of Arid Environments 37 (3): 443-452.

7. M. Jaffe and O. Al-Jayyousi, 2002. Planning models for sustainable water resources development. Journal of Environmental Planning and Management 45 (3): 309-322.

8. M. Mohsen, 2007. Water strategies and potential of desalination in Jordan. Desalination 203 (1-3): 2746.

9. M. Abu-Zreig, M. Attom and N. Hamasha, 2000. Rainfall harvesting using sand ditches in Jordan. Agricultural Water Management 46 (2): 183-192.

10. M. Mohsen and J. Jaber, 2002. Potential of industrial wastewater reuse. Desalination 152: 281-289. 